EXEMPLARITY AND MEDIOCRITY 



\title{
Exemplarity and Mediocrity
}

\author{
The Art of the Average \\ from Bourgeois Tragedy to Realism
}

PAUL FLEMING

STANFORD UNIVERSITY PRESS STANFORD, CALIFORNIA 2009 
Stanford University Press

Stanford, California

(C) 2009 by the Board of Trustees of the Leland Stanford Junior University. All rights reserved.

No part of this book may be reproduced or transmitted in any form or by any means, electronic or mechanical, including photocopying and recording, or in any information storage or retrieval system without the prior written permission of Stanford University Press.

Printed in the United States of America on acid-free, archival-quality paper

Library of Congress Cataloging-in-Publication Data

Fleming, Paul

Exemplarity and mediocrity : the art of the average from bourgeois tragedy to realism / Paul Fleming.

p. $\mathrm{cm}$.

Includes bibliographical references and index.

ISBN 978-o-8047-5890-1 (cloth : alk. paper)

1. German literature-18th century-History and criticism. 2. German literature-19th century-History and criticism. 3. Aesthetics in literature.

I. Title.

PT289.F58 2008

$830.9^{\prime} 384-\mathrm{dc} 22$

2008007443

Typeset by Thompson Type in 10/12.5 Palatino 